\title{
PENGEMBANGAN PAKET BIMBINGAN BERBASIS EXPERIENTIAL LEARNING UNTUK MENINGKATKAN EMPATI SISWA SEKOLAH DASAR
}

\author{
Santy Andrianie, Muslihati, M. Ramli \\ Universitas Negeri Malang, Jalan Semarang 5 Malang 65145 \\ Email: sun.andreany.bestar2@gmail.com
}

\begin{abstract}
This research is motivated by the rise of violence in schools that have not been handled properly. The purpose of this study is to produce a product in the form of experiential learningbased guidance package to improve the empathy of elementary school students are theoretically effective and practical. The development model used Borg and Gall model. Quantitative data was analyzed by quantitative calculation and input / suggestion was analyzed descriptively. The results of this study are teacher books and student books. Based on expert assessment and prospective user assessment in small group test, these two products are assessed to meet the development criteria of accuracy, usefulness, convenience, and attractiveness. The level of acceptability of both products is passably, judging from the expert assessment index and the assessment of potential users.
\end{abstract}

Keywords: guidance; empathy; experiential learning

\begin{abstract}
Abstrak: Penelitian ini dilatarbelakangi oleh maraknya tindak kekerasan di lingkungan sekolah yang belum ditangani dengan tepat. Tujuan penelitian ini adalah menghasilkan produk berupa paket bimbingan berbasis experiential learning untuk meningkatkan empati siswa sekolah dasar yang efektif secara teoretik dan praktik. Model pengembangan yang digunakan adalah model Borg dan Gall yang diadaptasi. Data kuantitatif dianalisis dengan penghitungan kuantitatif dan masukan/saran dianalisis secara deskriptif. Hasil penelitian ini berupa buku guru dan buku siswa. Berdasarkan penilaian ahli dan penilaian calon pengguna dalam uji kelompok kecil, kedua produk ini dinilai memenuhi kriteria pengembangan berupa ketepatan, kegunaan, kemudahan, dan kemenarikan. Tingkat keberterimaan kedua produk cukup baik, dilihat dari indeks penilaian ahli dan penilaian calon pengguna.
\end{abstract}

Kata kunci: bimbingan; empati; experiential learning

Dewasa ini, fenomena kekerasan semakin sering menghiasi media nasional. Sebuah lembaga yang bergerak di bidang pendidikan yang memusatkan perhatian pada usaha pengaktualisasian diri terhadap nilai-nilai luhur yakni integritas, empati, respek, toleran, dan tanggung jawab, tingkat kekerasan di Indonesia terus meningkat, baik dari sisi jumlah, jenis, maupun kualitasnya. Lebih dari itu, pelaku maupun korban makin beragam, baik ditinjau dari jenis kelamin, latar belakang, maupun tingkatan usia (Sejiwa, 2014). Fenomena kekerasan di sekolah yang dilakukan oleh teman sebaya di Indonesia semakin meningkat. Salah satunya adalah kasus kekerasan di sekolah dasar yang berada di Bukit Tinggi, dimana korbannya adalah seorang siswi yang dikeroyok oleh beberapa teman laki-lakinya (Detiknews, 2014).

Peristiwa tersebut terjadi di dalam kelas saat jam pelajaran berlangsung. Kasus kekerasan di sekolah lainnya terjadi di Temanggung, Jawa Tengah. Peristiwa yang tidak terpaut lama dari peristiwa di Bukit Tinggi ini terjadi pada seorang siswa yang dipukuli oleh beberapa teman lakilakinya (Detiknews, 2014). Bertolak pada kasuskasus kekerasan oleh siswa sekolah dasar ini, beberapa sekolah mengambil tindakan tegas untuk menyelamatkan para siswanya. Kebanyakan penyelesaian yang diambil adalah memindahkan 
pelaku kekerasan ke sekolah lain atau bahkan mengeluarkan siswa tersebut dari sekolah. Sementara itu, penyelesaian ini tidak benar-benar menyelesaikan masalah karena cara ini tidak memutus mata rantai tindak kekerasan. Meskipun tidak dipungkiri bahwa cara ini bisa memberi efek jera pada pelaku, namun tidak pula dapat dipastikan bahwa pelaku akan "mencetak" pelaku-pelaku lain di tempatnya yang baru.

Berdasarkan penelitian yang dilakukan Saripah, karakterisktik pelaku kekerasan yang merujuk pada bullying adalah memiliki kemampuan empati yang rendah serta tingkat agresivitas yang tinggi (Saripah, 2010). Kemampuan empati yang rendah ditunjukkan dengan sikap senang melihat orang lain dalam kesulitan, tidak merasa bersalah setelah menyakiti fisik/psikis orang lain, mengutamakan kepentingan diri sendiri, tidak menunjukkan penghargaan pada orang lain, tidak memikirkan konsekuensi dari suatu perbuatan, dan senang menonjolkan diri. Siswa Sekolah Dasar (SD) adalah kelompok usia anak-anak yang sedang mengalami perubahan dan perkembangan diri dalam segala aspek.

Salah satu perkembangan diri yang dialami mereka adalah pekembangan sosioemosional. Empati merupakan salah satu konstruk yang membantu perkembangan sosioemosional anak. Empati merupakan kemampuan memahami perasaan dan kekhawatiran orang lain (Borba, 2008). Dengan empati anak dapat memahami, merasakan, menghayati orang lain karena dalam proses empati ini berlangsung proses pengertian dan perasaan yang dinyatakan bentuk hubungan antar pribadi. Ketrampilan empati yang baik akan membantu anak untuk mampu mengendalikan perilakunya yang mengarah pada kekerasan. Berdasarkan hal ini, sekolah dapat mencegah kekerasan yang terjadi disekolah dengan meningkatkan empati pada diri siswa.

Bagi siswa sekolah dasar, kemampuan berempati merupakan suatu kebutuhan. Hal ini sejalan dengan Standar Kompetensi Kemandirian pada Siswa Sekolah Dasar khususnya dalam aspek perkembangan landasan perilaku etis, kematangan emosi, kesadaran tanggung jawab sosial, pengembangan diri, serta kematangan hubungan dengan teman sebaya. Hal ini menunjukkan bahwa kemampuan untuk memiliki perilaku empati perlu dikembangkan. Penanaman empati sebagai inti dari pendidikan moral atau budi pekerti akan mampu menyentuh perkembangan perilaku siswa secara mendasar, apabila penanaman empati tersebut ditanamkan pada siswa sejak usia dini. Jika penanaman empati tersebut diberikan pada siswa setelah menginjak dewasa maka tidak akan begitu berpengaruh secara mendasar terhadap karakter dan pembentukan pribadi siswa.

Implikasi darihal tersebutadalah siswa sekolah dasar perlu mendapatkan bekal kemampuan untuk menjalani kehidupannya. Siswa perlu memperoleh pengalaman belajar dan mengembangkan kemampuan empatinya. dasar merupakan salah satu jenjang pendidikan yang harus mendapatkan pelayanan bimbingan dan konseling. Meskipun demikian, saat ini guru bimbingan dan konseling di jenjang sekolah dasar masih jarang ditemui. Oleh karena itu, pengembangan empati sebagai aspek yang perlu ditumbuhkan dalam layanan bimbingan dan konseling pada siswa memerlukan strategi yang dapat diintegrasikan dalam proses pembelajaran. Sejauh ini, media pelaksanaan bimbingan dan konseling di sekolah dasar masih minim.

Hal ini berbanding terbalik dengan kebutuhan siswa sekolah dasar akan bimbingan dan konseling dalam membantu pencapaian kemandirian mereka. Keberadaan guru bimbingan dan konseling (konselor) yang masih jarang ditemui di sekolah juga masih jarang ditemui di seting sekolah dasar. Sejauh ini, kegiatan bimbingan di sekolah dasar dilakukan oleh guru kelas dengan keterampilan yang tidak memadai. Oleh sebab itu, dibutuhkan suatu media yang dapat membantu guru sekolah dasar melaksanakan kegiatan layanan bimbingan dan konseling.

Experiential learning merupakan model pembelajaran yang menekankan pada aktivitas mengalami, merefleksikan, dan melakukan tindakan, sehingga daripemahamandanpengalaman selama proses belajar akan membentuk suatu pemahaman baru. Seorang siswa dikatakan berhasil setelah mendapatkan pelatihan melalui model ini apabila siswa tersebut: (1) mampu mendapatkan pengalaman secara langsung; (2) mampu merefleksikan pengalaman yang diperoleh secara langsung; (3) mampu mengkonsepualisasikan pengalaman yang diperoleh secara tepat sehingga 
memperoleh sebuah konsep yang baru; dan (4) mampu menerapkan konsep baru yang diperoleh dalam kehidupan nyata.

Model pembelajaran experiential learning dianggap tepat untuk meningkatkan empati pada siswa. Hal ini didasarkan pada konsep model ini yang tidak hanya menginterfensi ranah kognitif, namun juga ranah afektif. Kedua ranah ini akan berpengaruh dalam tindakan sosial atau perilaku individu. Pemahaman dan kesadaran diperlukan untuk pertimbangan individu melakukan suatu tindakan yang efektif di lingkungan sosial. Oleh karena itu, pemilihan model intervensi yang tepat akan memberikan stimulus yang tepat dalam mengembangkan kedua aspek tersebut. Metode ini membuat anak menjadi peka terhadap kebutuhan dan perasaan orang lain, mendorong anak menolong orang yang kesusahan atau kesakitan, serta menuntut anak untuk memperlakukan orang dengan kasih sayang. Meningkatnya ketrampilan empati pada siswa diharapkan dapat mencegah tindak kekerasan atau perilaku bullying siswa.

Model experiential learning merupakan suatu model pembelajaran yang sudah banyak digunakan oleh guru sekolah dasar. Hal ini menjadi penguat penggunaan metode ini dalam mengembangkan paket bimbingan peningkatan empati, karena guru telah memahami prinsip dan langkah-langkah pelaksanaan model experiential learning, sehingga mempermudah pengaplikasian paket bimbingan peningkatan empati nantinya. Pemilihan media yang dikembangkan berupa suatu paket bimbingan, didasarkan pada prinsip paket yang berupa kegiatan berkesinambungan yang memuat suatu materi. Prinsip ini mendukung tujuan dari penelitian pengembangan ini yang memiliki tujuan untuk meningkatkan ketrampilan empati siswa.

Sedangkan kegiatan bimbingan dipilih sebagai upaya pencegahan, karena pengembangan paket bimbingan ini dilaksanakan di sekolah dasar yang siswanya masih berada pada usia penanaman karakter, sedangkan siswa yang memiliki penanganan khusus harus diberikan pelayanan tersendiri. Kekerasan di sekolah dasar saat ini perlu segera mendapat penyelesaian. Kegiatan bimbingan di sekolah dasar ditugaskan pada guru kelas yang tidak memiliki kemampuan yang cukup untuk melaksanakan layanan bimbingan dan konseling. Seorang pelaku kekerasan memiliki tingkat empati yang rendah. Experiential learning merupakan suatu model pembelajaran yang sudah akrab digunakan bagi pendidik.

\section{METODE}

Penelitian ini menggunakan model Reserch and Divelopment (R\&D). Sasaran utama R \& D bukan merumuskan atau mengkaji teori tertentu, melainkan mengembangkan suatu produk tertentu untuk penggunaannya di sekolah. R \& D berbicara tentang siklus (Semiawan, 2007). Siklus R \& D yang mencakup penemuan penelitian terhadap produk yang akan dihasilkan, mengkajinya kembali dimana hasil tersebut digunakan dan merevisinya sampai kajian tersebut dianggap memadai. Pada penelitian pengembangan ini, peneliti hanya melakukan sampai tahap ke lima, yaitu melakukan penelitian dan mengumpulkan informasi, melakukan perencanaan, mengembangkan bentuk produk awal, melakukan penilaian ahli terhadap produk dan uji coba lapangan, dan melakukan revisi produk utama. Subjek penilaian ahli yang dipilih adalah ahli Bimbingan dan Konseling serta ahli media, dengan kriteria: (1) dosen Bimbingan dan Konseling dan Teknologi Pendidikan; (2) telah menempuh pendidikan minimal S2; dan (3) telah menjadi dosen minimal selama 5 tahun. Subjek uji calon pengguna produk yang dipilih pada tahap kedua adalah 2 orang guru SDN Bulu, Purwoasri yang telah menjadi pegawai negeri dan minimal mengajar selama 10 tahun dan 28 siswa SDN Bulu, Purwoasri yang duduk di kelas V.

Instrumen pengumpulan data pada tahap ini adalah angket penilaian pengembangan paket bimbingan berbasis experiential learning untuk meningkatkan empati siswa sekolah dasar. Instrumen pengumpulan data yang digunakan adalah angket penilaian yang dilengkapi dengan lembar saran perbaikan. Penilaian pada tahap ini dimaksudkan untuk mengetahui tingkat keterterimaan paket bimbingan berbasis experiential learning untuk meningkatkan empati siswa sekolah dasar. Analisis data angka yang diperoleh dari penilaian ahli (ahli Bimbingan dan Konseling serta Ahli Media) dilakukan dengan analisis inter-rater agreement (Gregory, 2011). Sementara itu, data yang diperoleh dari calon pengguna dianalisis dengan menggunakan persentase. Data kuantitatif dari calon pengguna 
berupa saran dan komentar dianalisis secara deskriptif (Gunawan, 2016; Hadi, et al., 2018) untuk penyempurnaan paket bimbingan berbasis experiential learning untuk meningkatkan empati siswa sekolah dasar.

\section{HASIL}

Secara umum, hasil penilaiaian para ahli dan calon pengguna terhadap produk adalah baik. Secara rinci, kesepakatan antar penilai (inter-rater agreement) terhadap produk buku siswa adalah 1 (satu). Jika didasarkan pada pedoman kriteria yang digunakan untuk interpretasi hasil perhitungan indeks penilaian ahli secara keseluruhan dapat dilihat bahwa produk buku siswa dari paket bimbingan berbasis experiential learning untuk meningkatkan empati siswa sekolah dasar ini dinilai baik. Skala 1 (satu) ini menujukan bahwa, menurut ahli, produk sudah tepat dengan materi yang mendasari, berguna bagi siswa, mudah dipahami oleh siswa, dan menarik.

Kesepakatan antar penilai (inter-rater agreement) terhadap produk buku guru adalah 1 (satu). Jika didasarkan pada pedoman kriteria yang digunakan untuk interpretasi hasil perhitungan indeks penilaian ahli maka secara keseluruhan dapat dilihat bahwa produk buku guru dari paket bimbingan berbasis experiential learning untuk meningkatkan empati siswa sekolah dasar ini dinilai baik. Skala 1 (satu) ini menujukan bahwa menurut para guru, secara umum produk sudah tepat dengan materi yang mendasari, memiliki kegunaan yang tepat untuk guru, dan mudah dipahami. Secara umum, berdasarkan penilaian calon pengguna, buku guru yang dihasilkan memiliki rata-rata skor 3,88 yang artinya sangat berguna bagi konselor, mudah dilaksanakan, dan menarik.

Penilaian siswa terhadap buku siswa dalam uji kelompok kecil,dapat dilihat secara umum menurut calon pengguna buku siswa, yaitu siswa kelas V SDN Bulu, Purwoasri bahwa produk buku siswa memiliki tingkat keberterimaan rata-rata skor 3,63 yang artinya sangat baik. Siswa menilai bahwa buku siswa dari paket bimbingan berbasis experiential learning untuk meningkatkan empati siswa sekolah dasar ini mudah untuk dipahami dan menarik.

Saran dan masukan dari ahli dan calon pengguna adalah: (1) langkah kerja guru sebaiknya lebih konkrit dan terinci; (2) tahapan experiential learning perlu lebih diperjelas dalam tiap langkah kerja guru; (3) pemilihan kata pada bagian kata pengantar perlu lebih lugas, sehingga "dekat" dengan bahasa siswa; (4) pemilihan sampul perlu lebih menarik dan berwarna; (5) sebaiknya ada penjelasan mengenai langkah experiential learning sebagai pedoman guru melaksanakan kegiatan bimbingan peningkatan empati; dan (6) sebaiknya dalam buku guru disertai pedoman penilaian skala empati.

\section{PEMBAHASAN}

Pengembangan paket bimbingan berbasis experiential learning untuk meningkatkan empati siswa sekolah dasar ini bertujuan untuk membantu guru dalam mengembangkan kemampuan berempati siswa sekolah dasar. Paket bimbingan berbasis experiential learning untuk meningkatkan empati siswa sekolah dasar ini bersifat sebagai salah satu alat bantu untuk mempermudah guru dan siswa dalam upaya pengembangan kemampuan empati siswa dengan tanpa mengesampingkan hubungan antara guru dan siswa (Gunawan, 2018). Penelitian pengembangan ini menghasilkan produk akhir berupa paket bimbingan berbasis experiential learning untuk meningkatkan empati siswa sekolah dasar bagi siswa sekolah dasar. Paket bimbingan ini terdiri dari buku siswa dan buku guru, dimana dalam langkah kerjanya menggunakan prinsipprinsip metode experiential learning sebagai pedoman pelaksanaan kegiatan pembelajaran.

Buku guru digunakan sebagai pegangan atau panduan untuk konselor berisi pengantar atau penjelasan bagi konselor tentang tata cara pelaksanaan bimbingan peningkatan empati, materi yang dapat digunakan dalam pelaksanaan paket bimbingan peningkatan empati dan petunjuk penggunaan buku siswa, sementara buku siswa berisi materi atau informasi untuk siswa, latihanlatihan isian untuk siswa serta tempat bagi siswa untuk mengekspresikan perasaannya dalam kolom tersendiri. Buku siswa dilengkapi dengan gambar serta warna-warna yang menarik sebagai ilustrasi untuk memudahkan siswa dalam memahami materi serta menambah daya kemenarikan paket bimbingan peningkatan empati.

Paket bimbingan peningkatan empati dikembangkan berdasarkan beberapa kriteria, 
yaitu ketepatan, kegunaan, kemudahan, dan kemenarikan. Secara keseluruhan, kelima kriteria produk tersebut dapat terpenuhi. Hasil penilaian ahli dan uji calon pengguna dalam kelompok kecil menunjukkan tingkat keberterimaan produk cukup baik dengan skor inter-rater penilaian ahli mendapat skor 1 yang artinya produk dinilai baik dan keberterimaan pada calon pengguna mendapat skor di rentang 3,01 s.d. 4.00 yang artinya produk ini diterima dengan baik oleh calon pengguna. Hal ini dikarenakan dalam pengembangan produk selalu berpedoman pada teori yang mendasari, baik teori empati maupun experiential learning dan selalu memperhatikan kriteria pengembangan produk.

Penggunaan paket bimbingan peningkatan empati ini dinilai mudah untuk digunakan baik bagi siswa ataupun bagi guru. Hal ini bisa dilihat dari hasil penilaian ahli dan penilaian calon pengguna untuk aspek kemudahan yang masing-masing menunjukkan skor 1 untuk indeks inter-rater penilaian ahli, dan skor di rentang 3,01 s.d. 4,00 untuk penilaian calon pengguna. Paket bimbingan peningkatan empati ini dinilai mudah untuk dipahami dan dilaksanakan oleh guru karena dalam pengembangannya, buku guru diintegrasikan dengan buku siswa sehingga memudahkan guru melaksanakan kegiatan bimbingan. Buku guru juga dilengkapi dengan pedoman evaluasi yang memudahkan guru dalam mengevaluasi keberhasilan kegiatan bimbingan. Selain itu, waktu dan bentuk kegiatan juga disesuaikan dengan kegiatan belajar di sekolah dasar, sehingga memudahkan guru melakukan perencanaan dan pelaksanaan. Buku siswa dikembangkan dengan menggunaan bahasa dan media yang mudah dipahami oleh siswa (Kumintardjo \& Gunawan, 2017).

Produk ini dikembangkan dengan proses penilaian ahli, validasi melalui uji coba, dan revisi. Bagian yang telah direvisi berdasarkan saran ahli BK adalah pada Buku Guru, mengenai penjelasan tahapan pelaksanaan tahapan experiential learning. Sebelumnya dalam Buku Guru tidak dijelaskan mengenai tahapan experiential learning secara rinci, karena telah diterjemahkan ke dalam bahasa lugas media pembelajaran. Revisi dilakukan dengan menambahkan penjelasan yang lebih terperinci mengenai tahapan kegiatan experiential learning yang akan dilakukan selama kegiatan pelaksanaan paket bimbingan. Hal lain yang telah disempurnakan menurut Ahli BK dan Ahli Media adalah mengenai teknis fisik produk berupa pemilihan sampul, desain media, serta pemilihan kata dalam bagian "Kata Pengantar". Proses revisi dilakukan dengan merubah sampul, desain media serta kata-kata dalam "Kata Pengantar" sehingga lebih komunikatif dan menarik.

Setelah dilakukan penilaian ahli, dengan beberapa revisi produk sesuai saran dan kritik dari ahli penilai, maka paket bimbingan peningkatan empati yang berupa buku guru dan buku siswa diuji cobakan pada kelompok kecil yaitu konselor di sekolah dan siswa. hasil uji kelompok kecil yang dilakukan di SDN Bulu, Purwoasri, didapatkan bahwa respon dan keberterimaan produk cukup tinggi. Secara umum berdasakan hasil penilaian subjek uji coba masing-masing buku mendapatkan skor yang berada di rentang 3,01 s.d. 4,00. Kategori tersebut adalah kategori tertinggi yang didukung dengan tanggapan-tanggapan positif sebagai indikator yang juga menunjukan bahwa produk yang dihasilkan sangat berguna dan sangat mudah untuk diapliksikan oleh konselor dan mudah dipahami oleh siswa. Konten bimbingan yang terdapat didalamnya juga dinilai menarik dan tidak membosankan. Dengan demikian, dapat disimpulkan bahwa paket bimbingan berbasis experiential learning untuk meningkatkan empati siswa sekolah dasar ini sangat memuaskan bagi calon pengguna (konselor dan siswa). Hal ini menunjukkan bahwa tingkat keterterimaan paket bimbingan berbasis experiential learning untuk meningkatkan empati siswa sekolah dasar ini sangat tinggi.

Setelah dilakukan penilaian oleh ahli dan uji coba kelompok kecil, produk yang dihasilkan dalam penelitian pengembangan ini adalah paket bimbinngan peningkatan empati berbasis experiential learning. Paket bimbingan peningkatan empati ini memiliki beberapa keunggulan, antara lain: (1) menjadi salah satu media alternatif yang dapat digunakan untuk membantu konselor menyelesaikan masalah rendahnya ketrampilan berempati siswa di sekolah dasar; (2) paket bimbingan ini dapat dilaksanakan dengan mudah dan efisien dalam hal waktu, dana, serta tenaga; dan (3) media yang digunakan 
fleksibel, sehingga konselor dapat memaksimalkan kegiatan bimbingan sesuai dengan fasilitas yang ada di sekolahnya.

Selain keunggulan-keunggulan yang telah disebutkan diatas, produk yang dihasilkan juga memiliki beberapa kelemahan. Adapun kelemahan dari produk paket bimbingan berbasis experiential learning untuk meningkatkan empati siswa sekolah dasar adalah: (1) belum adanya anggaran dalam pengadaan paket bimbingan; (2) tidak semua sekolah dasar memiliki konselor, sehingga perlu adanya pelatihan ketrampilan penggunaan paket bimbingan ini kepada guru kelas; (3) tidak adanya alokasi jam pelajaran yang bisa digunakan untuk pelaksanaan kegiatan bimbingan peningkatan empati, sehingga harus menambah di jam ekstra; dan (4) belum diketahui validitas berdasarkan uji lapangan sehingga dalam pengaplikasiannya harus melalui penelitian tindakan.

Bagi ilmu bimbingan dan konseling, produk paket bimbingan berbasis experiential learning untuk meningkatkan empati siswa sekolah dasar ini memberikan kontribusi dalam memperkaya media dalam pelaksanaan layanan dasar bimbingan dan konseling. Paket bimbingan ini dapat digunakan sebagai upaya preventif untuk mencegah perilaku agresif siswa yang merujuk pada perilaku bullying di kalangan pelajar. Paket bimbingan berbasis experiential learning untuk meningkatkan empati siswa sekolah dasar ini menjadi alternatif pemecahan masalah perilaku agresif di kalangan siswa (Hidayah, et al., 2017), dimana masih jarang memiliki konselor di sekolah. Dengan demikian, kehadiran paket bimbingan ini dapat memperkaya media bimbingan dan konseling di sekolah dasar.

Terkait dengan penelitian-penelitian sebelumnya mengenai empati dan bullying, produk penelitian ini mendukung hasil penelitian yang menjelaskan bahwa siswa yang berperilaku agresif memiliki empati yang rendah (Saripah, 2010). Hasil penelitian pengembangan ini dapat menjadi alternatif untuk mengatasi perilaku agresif siswa melalui pemberian bimbingan peningkatan empati. Penelitian dan pengembangan ini juga memperkuat penelitian keefektifan model experiential learning untuk meningkatkan empathic accuracy siswa (Septiana, 2012; Hardika, et al., 2018). Penelitian ini juga menggunakan metode experiential learning dapat digunakan untuk melatihkan empati secara efektif.

\section{KESIMPULAN}

Berdasarkan hasil revisi, dapat disimpulkan bahwa produk paket bimbingan berbasis experiential learning untuk meningkatkan empati siswa sekolah dasar ini layak untuk dilaksanakan dan dapat diterima oleh calon pengguna. Kelayakan produk didapatkan setelah melalui beberapa tahapan pengembangan yang dimulai dari analisis kebutuhan siswa hingga penilaian dari ahli media dan bimbingan dan konseling serta dari pengguna, yaitu guru kelas dan siswa kelas V sekolah dasar. Penilaian dari ahli dan calon pengguna inilah yang menjadi dasar untuk melakukan revisi produk, sehingga didapatkan produk yang layak serta efektif secara teoritis dan praktik.

\section{DAFTAR RUJUKAN}

Borba, M. (2008). Building Moral Intelligence. San Fransisco: Josey-Bass.

Gregory, R. J. (2011). Psycological Testing: History, Principles, and Aplications. Boston: Allyn and Bacon.

Gunawan, I. (2016). Pengantar Statistika Inferensial. Jakarta: Rajawali Pers.

Gunawan, I. (2018). Pengembangan Model Pembelajaran Kooperatif Berbasis Lesson Study di Perguruan Tinggi (Upaya Meningkatkan Keaktifan dan Hasil Belajar Peserta Didik). Malang: Universitas Negeri Malang, Penerbit UM Press.

Hadi, S., Gunawan, I., \& Dalle, J. (2018). Statistika Inferensial: Teori dan Aplikasinya. Jakarta: Rajawali Pers.

Detiknews. (2014). Lagi Siswa SD di Temanggung Dikroyok Teman Sekelas. Retireved 16 November 2018, from Detiknews Website: http://www.detiknews.com/read/2014/11 /16097896/12344569/156/Lagi!-SiswaSD-di-Temanggung-"Dikroyok"-TemanSekelas/08.30 pm/16-11-2014.

Detiknews. (2014). Menyedihkan Aksi Brutal Siswa SD Bukittinggi terjadi saat Pelajaran Agama, Retireved 16 November 2018, from Detiknews Website: http://www.detiknews. com/read/2014/11/16095752/12343053/15 6/Menyedihkan!-Aksi-“Brutal”-Siswa-SD- 
Bukittinggi-Terjadi-saat-Pelajaran-Agama/. Hardika, Aisyah, E. N., \& Gunawan, I. (2018). Facilitative Learning to Improve Student Learning Creativity. Paper presented at 3rd International Conference on Education Management and Administration (CoEMA 2018), Theme: The Challenges of Educational and Technology in Global and Local Era, Universitas Negeri Malang, Malang, 6-7 October 2018, (pp. 186-189). Published by Atlantis Press.

Hidayah, N., Hardika, Hotifah, Y., Susilawati, S. Y., \& Gunawan, I. (2017). Psikologi Pendidikan. Malang: Universitas Negeri Malang, Penerbit UM Press.

Kumintardjo, \& Gunawan, I. (2017). Manajemen Layanan Khusus. Malang: Universitas Negeri Malang, Penerbit UM Press.
Saripah, I. (2010). Model Kognitif Perilaku untuk Menanggulangi Perilaku Bullying (Model Konseling untuk Korban Bullying pada Siswa Sekolah Dasar). (Unpublished doctoral's disertation) Pascasarjana Universitas Pendidikan Indonesia, Bandung, Indonesia.

Sejiwa. (2014). Mengatasi Kekerasan di Lingkungan Anak. Retrieved 16 November 2018, from Sejiwa website: http://www. sejiwa.or.id./Mengatasi-Kekerasan-diLingkungan-Anak/.

Semiawan, C. R. (2007). Metode Penelitian Kualitatif. Jakarta: Grasindo.

Septiana, N. Z. (2012). Keefektivan Pelatihan Ketepatan Empati (Empathic Accuracy) dengan Menggunakan Model Experiential Learning Untuk Siswa SMK Jurusan Keperawatan. (Unpublished master's thesis) Pascasarjana Universitas Negeri Malang, Malang, Indonesia. 